\title{
Pearl Millet: A Green Bridge for Lepidopteran Pests
}

\author{
Bruna Magda Favetti ${ }^{1}$, Thaís Lohaine Braga-Santos ${ }^{1}$, Angélica Massarolli ${ }^{2}$, Alexandre Specht ${ }^{3}$ \\ \& Alessandra Regina Butnariu ${ }^{4}$ \\ ${ }^{1}$ Faculdade de Ciências Agronômicas de Botucatu, Universidade Estadual Paulista Júlio de Mesquita Filho, \\ Botucatu, SP, Brazil \\ ${ }^{2}$ Departamento de Zoologia, Setor de Ciências Biológicas, Universidade Federal do Paraná, Curitiba, PR, Brazil \\ ${ }^{3}$ Empresa Brasileira de Pesquisa Agropecuária, Brasília, DF, Brazil \\ ${ }^{4}$ Departamento de Ciências Biológicas, Universidade do Estado de Mato Grosso, Tangará da Serra, MT, Brazil \\ Correspondence: Bruna Magda Favetti, Faculdade de Ciências Agronômicas de Botucatu, Universidade Estadual \\ Paulista Júlio de Mesquita Filho, P.O. Box 237, 18610-307, Botucatu, São Paulo, Brazil. E-mail: \\ favettibruna@yahoo.com.br
}

Received: February 7, 2017

Accepted: April 5, 2017 Online Published: May 15, 2017

doi:10.5539/jas.v9n6p92

URL: https://doi.org/10.5539/jas.v9n6p92

\begin{abstract}
This study evaluated the occurrence of lepidopteran pests on millet cultivated in off-season in the state of Mato Grosso, Brazil. Larvae were collected from May to July 2013 in an area of 145 hectares located in Tangará da Serra, MT. After being collected, caterpillars were kept in the laboratory and fed an artificial diet until the pupal stage. After emergence, adults were dry mounted, identified, and deposited in the entomological collection of Embrapa Cerrados, Planaltina, Distrito Federal, Brazil. Adults obtained from 117 caterpillars were identified as Mocis latipes (Guenée), Spodoptera frugiperda (J.E. Smith), Helicoverpa armigera (Hübner), H. zea (Boddie), Mythimna (Pseudaletia) sequax Franclemont, Urbanus proteus (Linnaeus), and Leucania latiuscula Herrich-Schäffer. This study describes the first record of lepidopteran pests on millet plants in the state of Mato Grosso, and the incidence of lepidopterans in the system that uses millet as cover crop represents a risk of the occurrence of insect pests on subsequent crops on the straw of this grass.
\end{abstract}

Keywords: intermediate host, caterpillars, direct seeding.

\section{Introduction}

The area cultivated with pearl millet (Pennisetum glaucum L.) has expanded in Brazil, especially in the Cerrado, as one of the main cover crop alternatives for direct seeding (Priesnitz et al., 2011). The production system that includes millet after the summer crop and in late winter/early spring predisposes it and other cash crops, such as corn, sorghum, soybeans, sugarcane, and rice, to the attack of insects that use this cover crop as intermediate host (Perreira-Filho et al., 2003).

The number of pest insects attacking millet worldwide is extensive, comprising 458 listed species (Sharma \& Davies, 1988). Also, this crop may be attacked by groups of pests that are common to other grasses and some legumes. In an intensive cropping system, the various annual crops act as nearly permanent habitat for insects, allowing their populations to increase and facilitate their dispersion between crops (Perreira-Filho et al., 2003).

Therefore, the incidence of pests in this system that uses millet as cover crop represents a risk of attack by these insects on cash crops grown on millet straw.

Thus, given the importance of defoliating caterpillars in crops during the growing season, the present study was aimed at evaluating the occurrence of lepidopterans in millet in the Cerrado region in the state of Mato Grosso.

\section{Method}

The study was conducted in the Aparecida da Serra Farm $\left(14^{\circ} 18^{\prime} 59^{\prime \prime} \mathrm{S}, 57^{\circ} 45^{\prime} 16^{\prime \prime} \mathrm{W}, 560 \mathrm{~m}\right.$ in altitude), located between the municipalities of Tangará da Serra and Nova Marilândia, southwestern the of Mato Grosso state, Brazil. The millet variety used was ADR 7010, followed by soybean planting near areas sown with corn in March 2013. The plot consisted of 145 ha bordering a Cerrado area and an eucalyptus plantation. Sampling of caterpillars was carried out 48 days after planting until near harvest time (120 days). 
Twelve points were set up in a transect along the plot, with a distance between each point of 67 meters. At each point, the sampling method used was the linear meter with the aid of a measuring tape. The collected larvae were placed in plastic containers $(145 \mathrm{ml})$ and sent to the laboratory where they were individually placed in flat-bottomed tubes $(8 \mathrm{~cm} \times 2 \mathrm{~cm}$ in diameter) and fed an artificial diet (Greene, Leppla, \& Dickerson, 1976) until the pupal stage. Pupae were then removed and kept in plastic containers until adult emergence. Adults were dry mounted, sent for identification, and deposited in the entomological collection of Embrapa Cerrados, Planaltina, Distrito Federal, Brazil.

\section{Results and Discussion}

A total of 175 specimens was collected, of which 117 were identified. The remaining 58 specimens died during their development not completing the larval cycle. In order of frequency, adults of the following species were obtained: Mocis latipes (Guenée) (Lepidoptera: Noctuidae) (Figures 1A and 1B), Spodoptera frugiperda (Smith) (Lepidoptera: Noctuidae) (Figures 1H, 1I, and 1J), Helicoverpa sp. (Lepidoptera: Noctuidae) (Figures 1C, 1D, 1E, 1F, and 1G), Helicoverpa armigera (Hübner) (Lepidoptera: Noctuidae), Mythimna (Pseudaletia) sequax Franclemont (Lepidoptera: Noctuidae), Urbanus proteus (Linnaeus) (Lepidoptera: Hesperiidae), Helicoverpa zea (Boddie) (Lepidoptera: Noctuidae), and Leucania latiuscula Herrich-Schäffer (Lepidoptera: Noctuidae) (Table 1).

Mocis latipes and S. frugiperda were the most frequent species during sampling collections (Table 1). The attack of these caterpillars to soybean and cotton seedlings cultivated on pearl millet straw has been increasingly frequent, representing a risk to crops. Spodoptera frugiperda and M. latipes have a similar behavior to the black cutworm (Agrotis ipsilon), cutting the hypocotyl of seedlings, and consequently reducing the stand and yield (Soria \& Degrande, 2011).

Table 1. Species of lepidopteran pests found in millet plants in Mato Grosso, Brazil

\begin{tabular}{llll}
\hline Species & Common name & N & \% \\
\hline Mocis latipes (Guenée) (Lepidoptera: Noctuidae) & Small Mocis Moth & 61 & 52.0 \\
Spodoptera frugiperda (Smith) (Lepidoptera: Noctuidae) & Fall armyworm & 28 & 24.0 \\
Helicoverpa sp. (Lepidoptera: Noctuidae) & Helicoverpa & 12 & 10.0 \\
Helicoverpa armigera (Hübner) (Lepidoptera: Noctuidae) & Helicoverpa armigera & 09 & 8.0 \\
Mythimna sequax Franclemont (Lepidoptera: Noctuidae) & Wheat armyworm & 03 & 2.5 \\
Urbanus proteus (Linnaeus) (Lepidoptera: Hesperiidae) & Long-tailed skipper & 02 & 1.5 \\
Helicoverpa zea (Boddie) (Lepidoptera: Noctuidae) & Corn earworm & 01 & 1.0 \\
Leucania latiuscula Herrich-Schäffer (Lepidoptera: Noctuidae) & Leucania latiuscula & 01 & 1.0 \\
\hline
\end{tabular}



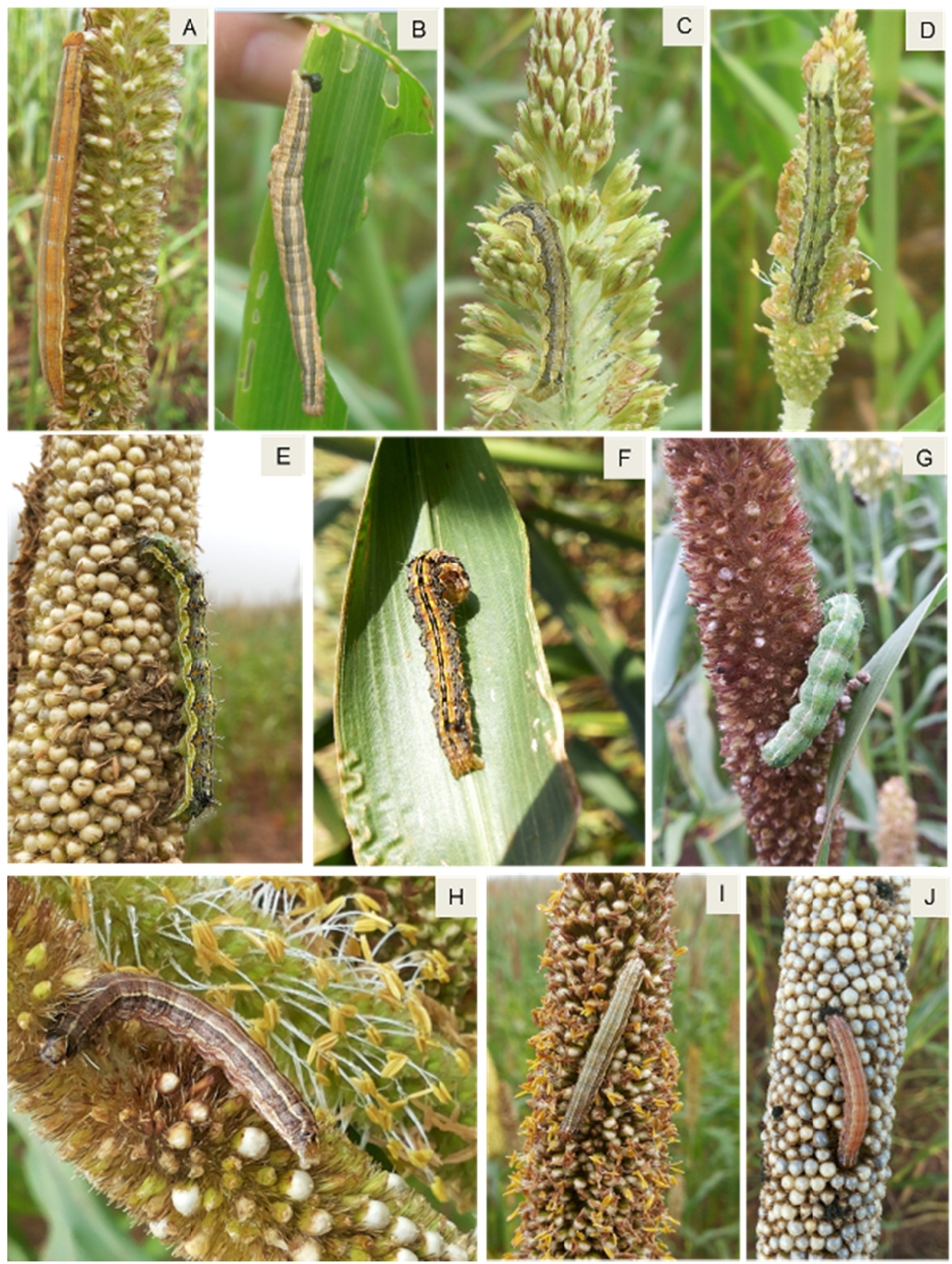

Figure 1. Some lepidopteran species found in pearl millet. Mocis latipes (A and B); Helicoverpa spp. (C, D, E, F, and G); Spodoptera frugiperda (H, I, and J). Source: Fabiano G. Schirmer

The occurrence of $H$. zea, H. armigera, and S. frugiperda in millet may be associated with the corn field nearby, as well as the succession with soybean crops, which can promote the migration and establishment of these species in the latter. Millet provides a green bridge to polyphagous species of the genus Spodoptera and Helicoverpa, which remain in the agro-ecosystem and may cause damage to subsequent corn and soybean crop. 
In recent years, $H$. armigera has been reported in different crops and Americas regions, and this new record in millet should reinforce attention with this pest in off-season crops (Czepak, Albernaz, Vivan, Guimarães, \& Carvalhais, 2013; Specht, Sosa-Gómez, Paula-Moraes, \& Yano, 2013; Murúa et al., 2014; Pratissoli, Lima, Pirovani, \& Lima, 2015; Kriticos et al., 2015; Krinski \& Godoy, 2015).

Caterpillars of M. sequax have been found in millet plants in Dourados, Mato Grosso do Sul (Soria \& Degrande, 2011). Although caterpillars of the genus Mythimna do not have a preference for soybeans grown on pearl millet straw, the damage to the stems of the plants, can lead to the death of plants, reducing the stand, similar to the observed for S. frugiperda and M. latipes (Tonet, Gassen, \& Salvadori, 2000).

It is known that sustainable practices in agriculture, such as no-tillage, have been stimulated in Brazil (Faleiros, 2011) and in the world, since this practice improves the chemical, physical and biological properties of the soil (Aziz, Mahmood, \& Islam, 2013). No-tillage, which was introduced in Brazil in the 1970s, and expanded in the 1990s, presents benefits to the environment (Marchão, 2007; Silva et al., 2007) and to the farmer (Cruz, 1999). However, in order to choose the most suitable cover crops, the producer must know the characteristics of the crop (Alvarenga et al., 2001) and the potential of these cover crops to be intermediate hosts for pests (Barros, Torres, Ruberson, \& Oliveira, 2010).

The choice of a cover crop without considering these criteria, favors the formation of a green bridge since the pests have food and micro habitats throughout the year, favoring mainly the species that are polyphagous (Oliveira, Auad, Mendes, \& Frizzas, 2014), as is the case of $S$. frugiperda, which has been registered in more than 80 plant species (Pogue, 2002), and H. armigera, registered in more than 60 species of cultivated and wild plants and in about 67 host families (Fitt, 1989; Pogue, 2004) and both have been recorded in the present survey in millet culture and are pests that occur in subsequent cultures in the study region.

Studies that aim to evaluate the adaptability of the pests cover crops are essential to assist in the correct choice. In a study conducted by Dias et al. (2016), evaluated sunflower (Helianthus annuus), sun hemp (Crotalaria juncea), brachiaria (Urochloa decumbens e Urochloa ruziziensis), millet (Pennisetum americanum), black oat (Avena stringosa), white lupin (Lupinus albus), forage turnip (Rafanus sativus) and maize (Zea mays), which are the main cover crops used in Brazil, and found that $C$. juncea presented a lower susceptibility to $S$. frugiperda attack, being therefore a promising species for cover of the soil preceding crops that are susceptible to the attack of this pest.

It is worth mentioning that in regions where there is a severe winter in the period between harvests, the lepidopteran pest cycle can be interrupted, thus reducing its populational abundance. However, in places that there is no this climatic fator for reduce the pests in ambient (such as the Cerrado, where this study was carried out), the period between harvests are cultivated with the cover plants as is the case of millet, which favors the maintenance and increased populations of lepidopteran pest.

Thus, this study describes the first record of lepidopteran pests on millet plants in the state of Mato Grosso. In the cultivation system practiced in the Brazilian midwest, cover crops, such as millet, act as a green bridge for insects, facilitating their migration between crops and maximizing the damage caused by these pests. Thus, the incidence of lepidopterans in the system that uses millet as cover crop represents a risk of the occurrence of insect pests on subsequent crops on the straw of this grass.

\section{Acknowledgements}

The authors thank the Franciosi Group for transferring the area of study and the State University of Mato Grosso, for the logistic support in the execution of the work.

\section{References}

Alvarenga, R. C., Cabezas, W. A. L., Cruz, J. C., \& Santana, D. P. (2001). Plantas de cobertura de solo para sistema plantio direto. Informe Agropecuário, 22, 25-36.

Aziz, I., Mahmood, T., \& Islam, K. R. (2013). Effect of long term no-till and conventional tillage practices on soil quality. Soil and Tillage Research, Amsterdam, 131, 28-35. http://dx.doi.org/10.1016/j.still.2013.03.002

Barros, E. M., Torres, J. B., Ruberson, J. R., \& Oliveira, M. D. (2010). Development of Spodoptera frugiperda on different hosts and damage to reproductive structures in cotton. Entomologia Experimentalis et Applicata, Dordrecht, 137, 237-245. https://doi.org/10.1111/j.1570-7458.2010.01058.x

Cruz, J. C. (1999). No plantio direto o milho é o melhor. Cultivar, Pelotas, 1(8), $28-29$. 
Czepak, C., Albernaz, K. C., Vivan, L. M., Guimarães, H. O., \& Carvalhais, T. (2013). First reported occurrence of Helicoverpa armigera (Hübner) (Lepidoptera: Noctuidae) in Brazil. Pesquisa Agropecuária Tropical, 43(1), 110-113. https://dx.doi.org/10.1590/S1983-40632013000100015

Dias, A. S., Marucci, R. C., Mendes, S. M., Moreira, S. G., Araújo, O. G., Santos, C. A., \& Barbosa, T. A. (2016). Bioecology of Spodoptera frugiperda (Smith, 1757) in different cover crops. Bioscience Journal, 32, 337-345. http://dx.doi.org/10.14393/BJ-v32n2a2016-29759

Faleiros, G. (2011). Semeando Sustentabilidade. Colaboração Brasil Reino Unido sobre Agricultura de Baixo Carbono (p. 45). Brasília, DF: Embaixada Britânica. Retrieved from http://www.agricultura.gov.br/ arq_editor/file/Sala $\% 20 \mathrm{de} \% 20$ Imprensa/Publica $\% \mathrm{C3} \%$ A7\%C3\%B5es/SEMEANDO $\% 20$ SUSTENTABILI DADE.pdf

Fitt, G. P. (1989). The ecology of Heliothis species in relation to agroecosystems. Annual Review of Entomology, 34, 17-52. https://doi.org/10.1146/annurev.en.34.010189.000313

Greene, G. L., Leppla, N. C., \& Dickerson, W. A. (1976). Velvetbean caterpillar: A rearing procedure and artificial medium. Journal of Economic Entomology, 69, 487-488. https://doi.org/10.1093/jee/69.4.487

Krinski, D., \& Godoy, A. F. (2015). First Record of Helicoverpa armigera (Lepidoptera: Noctuidae) Feeding on Plectranthus neochilus (Lamiales: Lamiaceae) in Brazil. Florida Entomologist, 98(4), 1238-1240. http://dx.doi.org/10.1653/024.098.0434

Kriticos, D. J., Ota, N., Hutchison, W. D., Beddow, J., Walsh, T., Tay, W. T., \& Zalucki, M. P. (2015). The Potential Distribution of Invading Helicoverpa armigera in North America: Is It Just a Matter of Time? PLoS ONE, 10(3), e0119618. http://doi.org/10.1371/journal.pone.0119618

Marchão, R. L. (2007). Integração lavoura-pecuária num Latossolo do Cerrado: Impacto na física, matéria orgânica e macrofauna (p. 153). Tese (Doutorado), Universidade Federal de Goiás, Goiânia.

Murúa, M. G., Scalora, F. S., Navarro, F. R., Cazado, L. E., Casmuz, A., Villagrán, M. E., ... Gastaminza, G. (2014). First record of Helicoverpa armigera (Lepidoptera: Noctuidae) in Argentina. Florida Entomologist, 97(2), 854-856. http://dx.doi.org/10.1653/024.097.0279

Oliveira, C. M., Auad, A. M., Mendes, S. M., \& Frizzas, M. R. (2014). Crop losses and the economic impact of insect pests on Brazilian agriculture. Crop Protection, Guildford, 56, 50-54. https://doi.org/10.1016/ j.cropro.2013.10.022

Pereira-Filho, I. A., Ferreira, A. S., Coelho, A. M., Casela, C. R., Karam, D., Rodrigues, J. A. S., ... Waquil, J. M. (2003). Manejo da Cultura do Milheto. Embrapa, Circular técnica, 29. Sete Lagoas, MG.

Pogue, G. M. (2002). A world revision of the genus Spodoptera Guenée (Lepidoptera: Noctuidae). Memoirs of the American Entomological Society, Philadelphia, 43, 1-202. Retrieved from http://www.biodiversity library.org/item/118237\#page/9/mode/1up

Pogue, M. G. (2004). A new synonym of Helicoverpa zea (Boddie) and differentiation of adult males of $H$. zea and H. armigera (Hübner) (Lepidoptera: Noctuidae: Heliothinae). Annals of the Entomological Society of America, 97, 1222-1226. https://doi.org/10.1603/0013-8746(2004)097[1222:ANSOHZ]2.0.CO;2

Pratissoli, D., Lima, V. L. S., Pirovani, V. D., \& Lima, W. L. (2015). Occurrence of Helicoverpa armigera (Lepidoptera: Noctuidae) on tomato in the Espírito Santo state. Horticultura Brasileira, 33(1), 101-105. https://dx.doi.org/10.1590/S0102-053620150000100016

Priesnitz, R., Costa, A. C. T., Jandrey, P. E., Fréz, J. R. S., Júnior, J. B. D., \& Oliveira, P. S. R. (2011). Espaçamento entre linhas na produtividade de biomassa e de grãos em genótipos de milheto pérola. Semina, 32, 485-494. https://doi.org/10.5433/1679-0359.2011v32n2p485

Sharma, H. C., \& Davies, J. (1988). Insect and other animal pests of millets (p. 86). ICRISAT, Patancheru.

Silva, R. F., Tomazi, M., Pezarico, C. R., Aquino, A. M., \& Mercante, F. M. (2007). Macrofauna invertebrada edáfica em cultivo de mandioca sob sistemas de cobertura do solo. Pesquisa Agropecuária Brasileira, 42, 865-871. http://dx.doi.org/10.4025/actasciagron.v30i5.5974

Soria, M. F., \& Degrande, P. E. (2011). Artropodofauna associada a palhada em plantio direto. Revista Brasileira Milho e Sorgo, 10, 96-107. https://doi.org/10.18512/1980-6477/rbms.v10n2p96-107 
Specht, A., Sosa-Gómez, D. R., Paula-Moraes, S. V., \& Yano, S. A. C. (2013). Morphological and molecular identification of Helicoverpa armigera (Lepidoptera: Noctuidae) and expansion of its occurrence record in Brazil. Pesquisa Agropecuária Brasileira, 48(6), 689-692. https://dx.doi.org/10.1590/S0100-204X2013000 600015

Tonet, G. L., Gassen, D. N., \& Salvadori, J. R. (2000). Estresses ocasionados por pragas. In E. R. Bonato (Eds.), Estresses em soja (pp. 201-253). Passo Fundo: Embrapa Trigo.

\section{Copyrights}

Copyright for this article is retained by the author(s), with first publication rights granted to the journal.

This is an open-access article distributed under the terms and conditions of the Creative Commons Attribution license (http://creativecommons.org/licenses/by/4.0/). 